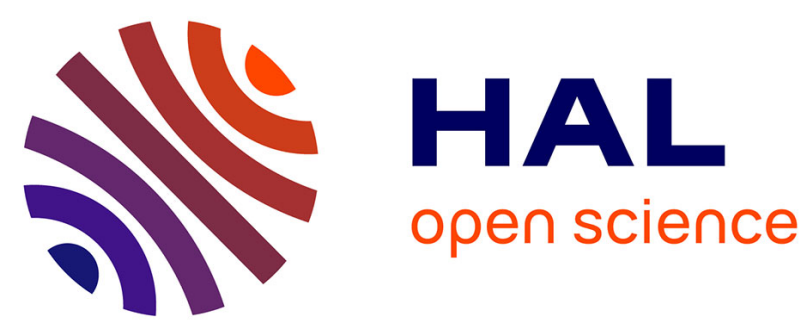

\title{
Physicochemical, techno-functional, and fat melting properties of spray-dried camel and bovine milk powders
}

Ahmed Zouari, Roua Lajnaf, Christelle Lopez, Pierre Schuck, Hamadi Attia, Mohamed Ali Ayadi

\section{- To cite this version:}

Ahmed Zouari, Roua Lajnaf, Christelle Lopez, Pierre Schuck, Hamadi Attia, et al.. Physicochemical, techno-functional, and fat melting properties of spray-dried camel and bovine milk powders. Journal of Food Science, 2021, 86 (1), pp.103-111. 10.1111/1750-3841.15550 . hal-03115051

\section{HAL Id: hal-03115051 \\ https://hal.inrae.fr/hal-03115051}

Submitted on 19 Jan 2021

HAL is a multi-disciplinary open access archive for the deposit and dissemination of scientific research documents, whether they are published or not. The documents may come from teaching and research institutions in France or abroad, or from public or private research centers.
L'archive ouverte pluridisciplinaire HAL, est destinée au dépôt et à la diffusion de documents scientifiques de niveau recherche, publiés ou non, émanant des établissements d'enseignement et de recherche français ou étrangers, des laboratoires publics ou privés.

\section{(ㅇ)(1) $\$$}

Distributed under a Creative Commons Attribution - NonCommercial - NoDerivatives| 4.0 


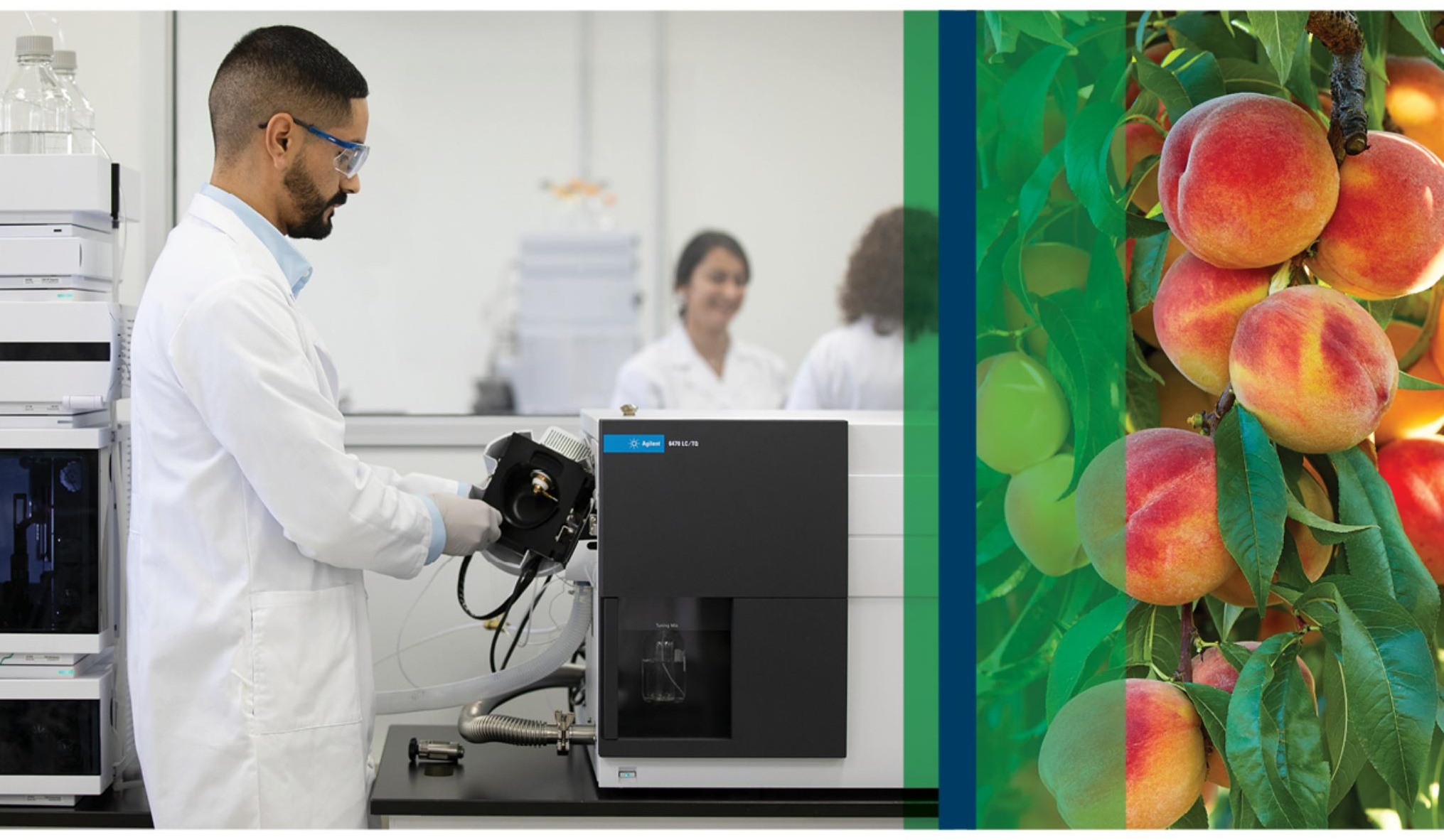

\section{Build Your Reputation on Unbelievably Robust Performance}

Agilent LC/MS triple quadrupole food testing solutions

From analyzing environmental contaminants to ensuring food safety, your demands for reliable, accurate results have never been greater. The Agilent 6470B LC/TQ gives you the peace of mind that you are delivering on your promises.

Download the e-book: LC/MS for Improved Analysis of Food and Water Contaminants

- Discover the wide range of food and environmental contaminants

- View real-world case studies from industry-leading experts

- Learn more about the future of LC/MS analysis

agilent.com/chem/6470b-portfolio

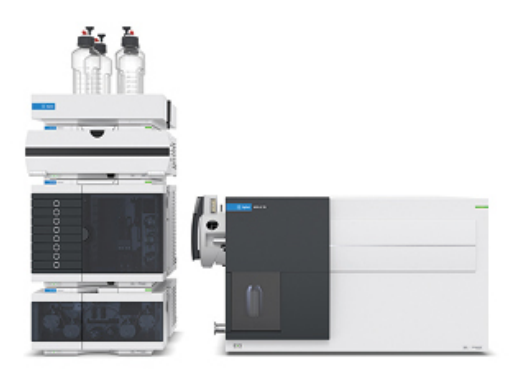




\title{
Physicochemical, techno-functional, and fat melting properties of spray-dried camel and bovine milk powders
}

\author{
Ahmed Zouari iD, Roua Lajnaf, Christelle Lopez, Pierre Schuck, Hamadi Attia, and Mohamed Ali Ayadi
}

\begin{abstract}
In this study, three skimmed and one whole-fat spray-dried camel milk powders were produced and their characteristics were compared to those of bovine milk powders. The physicochemical analysis of the produced powders indicated that camel milk powders (whether skimmed or not) presented higher ash and whey protein contents as compared to those of bovine milk powders. Our results indicated that the investigated camel and bovine milk powders exhibited a high solubility index $(>99 \%)$ with poor dispersibility and wettability indexes due to their small particles size $\left(d_{50} \leq\right.$ $12 \mu \mathrm{m}$ ) and their narrow size distribution (span $\leq 2$ ). In addition, although camel and bovine milk powders presented the same total fat content, lower free fat content was measured for camel milk powders. Besides, the whey protein nitrogen index and the SDS-PAGE electrophoresis underlined that camel and bovine milk proteins remained intact after drying with low denaturation extent. It is worth noticed that camel milk proteins were less denaturized due to the absence of the heat-sensitive $\beta$-lactoglobulin in camel milk. Moreover, the low denaturation extent participated in the enhancing of the foaming capacity and stability of camel and bovine milk powders. Finally, the calorimetric analysis showed that higher fat melting temperatures were recorded in whole-fat camel milk powder and in their anhydrous form as compared to those of bovine milk.
\end{abstract}

Keywords: spray drying, powder, dromedary milk, foam capacity, foaming, rehydration

Practical Application: Camel milk powder is an emerging non-bovine dairy product. Understanding its rehydration ability and evaluating the impact of spray drying on its protein quality are promising approaches to obtain high-quality camel milk powder with high reconstitution ability. Findings of this study indicated that spray drying is a suitable technique to produce highly soluble camel milk powders with low denaturation extent. These results will benefit the research and development department of food industry (especially those producing camel milk powder) as well as the direct consumers.

\section{INTRODUCTION}

A wide range of foods and food ingredients are commercialized in the form of powders. Indeed, powder systems offer several advantages to consumers and manufacturers, such as the shelf-life extension, the packaging and transport costs reduction, and manutention easiness. Actually, food powders (e.g., milk powders) are often produced using the spray-drying technology. This technique allows the production of milk powders with acceptable nutritional and functional properties (Sharma, Jana, \& Chavan, 2012). Most of the quality indicators of milk powders are related to their physicochemical composition (e.g., water activity and free fat amount), as well as their physical (e.g., particle size), techno-functional (e.g., rehydration and foaming), and sensorial (e.g., color and odor) properties.

During spray drying, water is evaporated in a brief heat exposure to dried-warm air. This exposure can modify the structure and functionalities of some heat-sensitive milk proteins (Zouari, Briard-Bion et al., 2020). The proteins denaturation and their subsequent aggregation may result in the loss of their functionality

$\overline{\text { JFDS-2020-0672 Submitted 4/24/2020, Accepted 11/8/2020. Authors Zouari, }}$ Lajnaf, Attia, and Ayadi are with Valuation, Security and Food Analysis Laboratory, National Engineering School of Sfax, Sfax University, Sfax, Tunisia. Authors Zouari, Lopez, and Schuck are with INRAE, STLO, Rennes, F-35000, France. Direct enquiries to author Zouari (E-mail: ahmedzouarrigmail.com). especially their rehydration and color properties (Haque, Bhandari, Gidley, Deeth, \& Whittaker, 2015; Sharma et al., 2012). The rehydration properties (i.e., solubility, dispersibility, and wettability) describe the reconstitution process of milk powders in water. Milk powders with reduced rehydration properties may impair their sensorial acceptability and techno-functional properties. One of the most important techno-functional properties of milk powders is the foaming properties. These properties are related to the interfacial properties of milk proteins, as well as their capacity to adsorb to the water-air interface.

Nowadays, the consumption spectra of camel milk is becoming wider and wider especially in many nonregular consuming countries. In general, camel and bovine milks present similar proximate composition. The proteins fraction of camel and bovine milks is essentially composed of caseins (around 80\%) and whey proteins (around 20\%) (Felfoul, Jardin, Gaucheron, Attia, \& Ayadi, 2017; Omar, Harbourne, \& Oruna-Concha, 2016). Actually, it was acknowledged that the camel milk proteins contain higher $\beta$-casein (47\%) and lower $\mathrm{K}$-casein $(3.5 \%)$ content than those of bovine milk (Omar et al., 2016; Zouari et al., 2018). Besides, the composition of bovine milk whey proteins showed a predominance of the $\beta$-lactoglobulin $(\beta-\mathrm{Lg})$ and the $\alpha$-lactalbumin $(\alpha-\mathrm{La})$. The particularity of camel milk whey is the lack of $\beta$-Lg, overexpression of $\alpha$-La, and the presence of some specific proteins, such as peptidoglycan recognition protein (PGRP) (Felfoul et al., 2017; Kappeler, Heuberger, Farah, \& Puhan, 2004; Lajnaf et al., 2018). 
Recent studies on camel milk powder have been focused on its particle structure and surface composition (Zouari, Schuck et al., 2020), as well as its behavior during drying (Habtegebriel, Edward, Wawire, Sila, \& Seifu, 2018; Zouari et al., 2019; Zouari, Mtibaa et al., 2020) and its physicochemical changes upon storage (Ho et al., 2019; Zouari, Briard-Bion et al., 2020). However, none of these explained the practical conditions to use skimmed or whole-fat camel milk powder in future applications. In this context, the objective of this study was to appraise the physicochemical characteristics of camel milk powders at different inlet $\backslash$ oulet drying temperatures $\left(160 \backslash 80^{\circ} \mathrm{C}, 180 \backslash 80^{\circ} \mathrm{C}\right.$, and $\left.200 \backslash 80^{\circ} \mathrm{C}\right)$. The free fat content, the loose and tapped bulk densities, the particles size distribution, and the rehydration properties (insolubility, dispersibility, and wettability indexes) were investigated. Then, the melting behavior of camel milk fat (anhydrous form and within the powder) was evaluated. Afterward, the SDS-PAGE was used to evaluate the denaturation extent of spray drying temperature on camel milk proteins. Finally, the foaming capacity (FC) and stability (FS) of skimmed (before drying) and reconstituted camel milks (after drying) were determined. To create a comparative study, we have also produced and evaluated bovine milk powders following the same drying conditions and the same evaluation techniques.

\section{MATERIALS AND METHODS}

\subsection{Milk samples}

Fresh whole-fat camel (Camelus dromedarius) and bovine (Bos taurus) milks were collected from two separated farms in southern Tunisia (Gabes and Sfax governorates, respectively). Milk samples were immediately stabilized against microbiological development with the addition of $0.02 \%(\mathrm{w} / \mathrm{w})$ of sodium azide and were transported to the laboratory within $2 \mathrm{hr}$ after milking. Thereafter, skimmed bovine and camel milks were obtained following one or three successive centrifugations $\left(2,000 \mathrm{~g}, 15 \mathrm{~min}\right.$, and $\left.5^{\circ} \mathrm{C}\right)$, respectively. The fat contents of whole-fat and skimmed camel and bovine milks were analyzed using Gerber method (Kleyn, Lynch, Barbano, Bloom, \& Mitchell, 2001).

\subsection{Drying conditions}

Camel and bovine milk samples, either whole-fat $(27 \mathrm{~g} / \mathrm{L})$ or skimmed $(<1 \mathrm{~g} / \mathrm{L})$, were spray-dried using a single stage mini spray dryer configured in cocurrent system (B-290 Büchi Labortechnik AG, Flawil, Switzerland). Each milk was introduced to the sprayer at $20{ }^{\circ} \mathrm{C}$. During all experiments, the absolute humidity of the inlet air was equal to $5 \mathrm{~g}$ of water per $\mathrm{kg}$ of dry air. The average droplets residence time in the drying chamber was equal to 1 $\mathrm{s}$ (experimentally determined). The rates of both drying air flow $\left(35 \mathrm{~m}^{3} / \mathrm{hr}\right)$ and pressurized air flow at the two-fluid atomizer nozzle $\left(47 \mathrm{~m}^{3} / \mathrm{hr}\right.$, corresponding to a pressure of $\left.0.41 \mathrm{bar}\right)$ were held constant. The milk feed rate was equal to $0.89 \pm 0.12 \mathrm{~kg} / \mathrm{hr}$. Under these drying conditions, three skimmed camel or bovine milk powders (unique trials) were produced using $160 \backslash 80^{\circ} \mathrm{C}, 180 \backslash 80$ ${ }^{\circ} \mathrm{C}$, and $200 \backslash 80^{\circ} \mathrm{C}$ as drying temperatures. The whole-fat camel or bovine milk powders were only produced using $200 \backslash 80^{\circ} \mathrm{C}$ as drying temperatures. The outlet drying temperature $\left(80^{\circ} \mathrm{C}\right)$ was maintained by slightly managing the feed rate. The standard deviation for all temperatures was equal to $2{ }^{\circ} \mathrm{C}$. At the end of the drying process, the powders were collected in sterilized glass vessel and placed at $4{ }^{\circ} \mathrm{C}$ until use.

\subsection{Physicochemical characterization of the powders}

The water activity of the produced powders was determined using an $a_{w}$-meter (Novasina RTD 200/0 and RTD 33, Pfäffikon, Switzerland). Camel and bovine milk powder compositions were determined as described by Schuck, Dolivet, and Jeantet (2012).

The free fat content was measured by mixing $10 \mathrm{~g}$ of camel or bovine milk powders for $5 \mathrm{~min}$ with $50 \mathrm{~mL}$ of petroleum ether (Schuck et al., 2012). The mixture was filtered through Whatman filter paper (Whatman $\mathrm{N}^{\circ} 40$, Maidstone, UK). Then, the obtained filtrate was evaporated at $60{ }^{\circ} \mathrm{C}$ under vacuum to remove the petroleum ether. The free fat content (expressed in $\mathrm{g} / 100 \mathrm{~g}$ of total fat of the analyzed powder) was measured using the following equation:

$$
\text { Free fat content }=\frac{\text { Weight of fat after evaporation }}{\text { Total fat of the analyzed powder }} \times 1000
$$

\subsection{Densities and size distribution of powder particles}

The loose bulk density and the tapped bulk density (150 tapes) of the produced powders were measured as described by Zouari et al. (2019) using a PT-N powder characteristics tester (Hosokawa Micron, Osaka, Japan).

The size distributions of skimmed camel and bovine milk powder particles were determined using a laser light scattering Mastersizer 2000 (Malvern Instruments Ltd., Malvern, UK), equipped with a dry powder feeder (Scirocco 2000, Malvern Instruments, Worchestershire, UK). The feeder was operating with a dispersion air pressure of 4 bars. The $d_{50}$ and the span (defined below) were chosen as size distribution indicators.

$$
\text { span }=\frac{d^{90}-d^{10}}{d^{50}}
$$

where $d_{10}, d_{50}$, and $d_{90}$ represent the particle size of the produced powders lying below 10,50 , and $90 \%$ of the whole distribution, respectively.

\subsection{Rehydration ability of the powders}

The rehydration ability of the produced powders was determined by considering the insolubility, wettability, and dispersibility indexes (DIs) as described by Schuck et al. (2012). Ten grams of each skimmed milk powder were vigorously mixed using a laboratory blender $(4,000 \mathrm{rpm})$ with $100 \mathrm{~mL}$ of MiliQ water and antifoaming agent (Octanol, 2 to 3 drops) at $20^{\circ} \mathrm{C}$ during $90 \mathrm{~s}$. Thereafter, the mixture was centrifuged at $160 \mathrm{~g}$ during $5 \mathrm{~min}$. The sediment volume (expressed in $\mathrm{mL}$ ) was recorded, which corresponded to the insolubility index.

The wettability time reflects the necessary time (expressed in min) to allow the total penetration of $10 \mathrm{~g}$ of camel and bovine milk powders in $100 \mathrm{~mL}$ of MiliQ water at $20{ }^{\circ} \mathrm{C}$ without disruption. After sinking, the wetted milk powder was then mixed with water using a glass spatula during $15 \mathrm{~s}$. The resulting mixture was filtered using a sieve of $200 \mu \mathrm{m}$ mesh size. The dry matter of the filtrate was then estimated by drying the filtrate at $105^{\circ} \mathrm{C}$ for $7 \mathrm{hr}$ in an oven. The DI was then determined following the below formula:

$$
D I=\frac{(W+w) \cdot X_{D M}}{w \cdot \frac{100-X_{R W}}{100}}
$$

where $W$ is water weight, $w$ is powder weight, $X_{D M}$ is dry matter of the filtrate $(\%, \mathrm{w} / \mathrm{w})$, and $X_{R W}$ is residual free water of the powder $(\%, w / w)$. 


\subsection{Denaturation extent of camel and bovine proteins}

2.6.1 Whey protein nitrogen index. The noncasein nitrogen $(\mathrm{NCN})$ and the nonprotein nitrogen $(\mathrm{NPN})$ were determined as described by Schuck et al. (2012). The whey protein nitrogen index (WPNI) was calculated as follows:

$$
W P N I\left(g N_{2} k_{g-1}\right)=\left(\frac{N C N}{6.25}-\frac{N P N}{6.19}\right) \times 10
$$

2.6.2 Sodium dodecyl sulphate-polyacrylamide gel electrophoresis. Sodium dodecyl sulphate-polyacrylamide gel electrophoresis (SDS-PAGE) was performed using $15 \%$ of polyacrylamide under reducing conditions as described by Laemmli (1970) with slight modifications. Skimmed and reconstituted camel and bovine milks were first diluted with ultrapure water $(2: 1, \mathrm{v} / \mathrm{v})$. Then, $5 \mu \mathrm{L}$ of diluted of each milk was added to $5 \mu \mathrm{L}$ of ultrapure water and $5 \mu \mathrm{L}$ of buffer solution (SDS: $10 \%(\mathrm{w} / \mathrm{w}) ; 0.5$ M $\beta$-mercaptoethanol; $0.5 \mathrm{M}$ tris- $\mathrm{HCl}(\mathrm{pH}=6.8)$; glycerol $2 \%$ $(\mathrm{w} / \mathrm{w})$; and bromophenol blue $0.1 \%(\mathrm{w} / \mathrm{w})$. Afterward, the mixture was heated for 4 min at $95^{\circ} \mathrm{C}$.

The electrophoresis analysis was carried out using a MiniProtean Tetra Cell (Bio-Rad Laboratories, Hercules, CA, USA) with a constant voltage of 120 Volt during $2 \mathrm{hr}$. After migration, proteins were detected by staining the gel for at least $30 \mathrm{~min}$ with a coloring mixture composed of Coomassie Blue R-250 (0.1\%,v/v), acetic acid (80\%), and ethanol (96\%). Finally, the gel was placed into two successive discoloration solutions (acetic acid (80\%), ethanol $(96 \%)$, and ultrapure water). The approximate molecular weight of each milk protein was evaluated using CLIQS Software (Version 1.1, TotalLab Ltd, Newcastle upon Tyne, UK) calibrated with molecular weights of known proteins (10 to $100 \mathrm{kDa}$, Promega Corporation, Durham, NC, USA).

\subsection{Differential scanning calorimetry}

The thermal properties of camel and bovine milk fat within the powders and in their anhydrous state were investigated using a differential scanning calorimeter (TA Q-1000, TA Instruments, Eschborn, Germany). The calibration of the DSC system was achieved with Indium (melting point $156.6^{\circ} \mathrm{C}$ ). About $10 \mathrm{mg}$ of each powder sample was sealed in aluminum hermetic pans. The behavior of fat within whole-fat milk powders was recorded from 0 to $65{ }^{\circ} \mathrm{C}$ by increasing the temperature with a rate of $1{ }^{\circ} \mathrm{C} / \mathrm{min}$. The anhydrous fat fractions of whole-fat camel and bovine milk powders were obtained by extracting the total fat (with hexane/isopropanol [3:1, v:v]). The melting profiles of these fractions were recorded from -30 to $65^{\circ} \mathrm{C}$ with a rate of $1{ }^{\circ} \mathrm{C} / \mathrm{min}$. The TA Universal Analysis 2000 software (Ta instruments, Waters LLC) was used to determine the melting characteristics of all analyzed fractions.

\subsection{Foaming properties}

The FC and stability of skimmed (before drying) and reconstituted (after drying) camel and bovine milk powder were determined as described by Lajnaf et al. (2018) with slight modifications. Ten milliliters $\left(\mathrm{V}_{0}\right.$, expressed in $\left.\mathrm{mL}\right)$ of each sample (proteins concentration $0.1 \%, \mathrm{w} / \mathrm{v}$ ) were whipped $\left(\right.$ at $25{ }^{\circ} \mathrm{C}$ ) in a graduated container (length $84 \mathrm{~mm}$; diameter $38 \mathrm{~mm}$ ) using an ULTRATURAX T 25 basic (IKA WERKE, Germany) at a rapid speed $(13,500 \mathrm{rpm})$ for $2 \mathrm{~min}$. The volume of whipped milks $\left(\mathrm{V}_{1}\right.$, ex- pressed in $\mathrm{mL}$ ) was immediately recorded and used to calculate the FC following the below equation:

$$
F C(\%)=\frac{V_{1}-V_{0}}{V_{0}} \times 100
$$

The foaming stability (FS) is defined as the necessary duration (expressed in seconds) to reduce the total foam volume by $50 \%$.

\subsection{Statistical analysis}

All performed analyses and measurements in this work were carried out in triplicate. The statistical differences were examined using SPSS 19 software following the Student's $t$-test, one-way ANOVA, and Tukey post-hoc test with a confidence level of $95 \%$.

\section{RESULTS AND DISCUSSION}

\subsection{Physicochemical characteristics}

3.1.1 Composition of the milks and powders. The compositions of whole-fat and skimmed camel or bovine milks are presented in Table 1. The results indicated that, whether skimmed or not, camel and bovine milks presented similar total solids, total protein, lactose, and fat contents $(P>0.05$, Table 1$)$. However both whole-fat and skimmed bovine milks contained significantly higher casein amounts as compared with camel milks $(P<0.05$, Table 1). It is important to note that whole-fat and skimmed camel milks presented higher whey protein and ash contents compared to bovine milks $(P<0.05$, Table 1$)$. These differences are in agreement with several other studies (Felfoul et al., 2016; Konuspayeva, Faye, \& Loiseau, 2009; Zouari, Briard-Bion et al., 2020). The latter studies indicated that the observed differences in camel and bovine milk composition mainly depend on the feeding characteristics and the water availability.

The physicochemical compositions of camel and bovine milk powders are presented in Table 1 . The water activity of both skimmed and whole-fat milk powders slightly ranged from 0.24 to 0.25 . This observation indicated that the fat did not interact with water during water activity measurement. Actually, it was demonstrated that fats were considered as nonreacting component with water and had no influence on the water activity of milk powders (Jouppila, Kansikas, \& Roos, 1997; Zouari, Schuck et al., 2020). In addition, Schuck et al. (2005) indicated that the water activity of nonfat and high-fat milk powders is mainly controlled by the moisture content of nonfat solids (i.e., proteins, lactose, and minerals). For all drying conditions, the total protein and the caseins fraction of bovine milk powders were significantly higher than those of camel milk powders $(P<0.05$, Table 1$)$. Moreover, the whey protein fraction of camel milk powders was significantly higher than that of bovine milk powders $(P>0.05$, Table 1$)$. Likewise, camel milk powders contained higher ash and lower lactose quantities $(P<0.05$, Table 1$)$. Moreover, both milk powders showed the same fat content (skimmed: $1 \mathrm{~g} / 100 \mathrm{~g}$ and whole-fat: $20.0 \mathrm{~g} / 100$ g). However, the free fat content in camel milk powders was in all cases lower than that observed in bovine milk powders $(P<0.05$, Table 2). Similar observations were reported by Zouari, Schuck et al. (2020). The latter indicated that camel milk fat was homogeneously distributed in the camel milk powder showing higher encapsulation degree. This was linked to the smaller mean diameter of camel milk fat globules compared to bovine milk fat globules (Karray, Lopez, Ollivon, \& Attia, 2005) and the higher mechanical resistance to disruption of camel milk fat globules as compared to those of bovine ones (Zouari, Schuck et al., 2020). These milk fat 


$$
\stackrel{0}{\circ}: \frac{0}{0} \quad \frac{0}{0}: \frac{0}{0}
$$$$
+H+H+H
$$

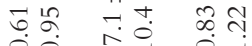

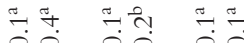

$$
\begin{aligned}
& \begin{array}{llll} 
& 0 & 0 & 0 \\
H & H & H
\end{array} \\
& \text { ते }
\end{aligned}
$$

\section{$\frac{\pi}{0} \frac{\pi}{0}$}

เึกับ กับ

in?

$\mathrm{H} H \mathrm{H}$

스유

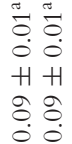

$\stackrel{0}{\circ} \frac{\pi}{0}$

$\frac{\pi}{0} \frac{\pi}{0}$

$H+H$

ㅇ. 0.0

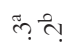

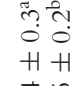
$+4$

ลิ่ ำ $\mathrm{H}+\mathrm{H}$ तิ तับ

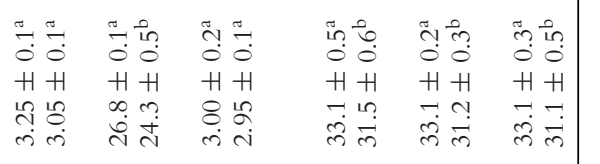
(1) U.
0
0
0<smiles>C1CC[C@@H]2CCC[C@H]2C1</smiles>

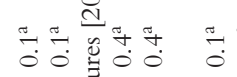
$\mathrm{H} H$ 局HH H

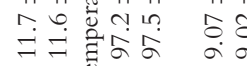

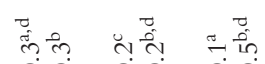
$\begin{array}{llll}0 & 0 & 0 & 0 \\ H & H & 0\end{array}$ $H+H \quad H \quad H+H$

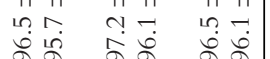
(बन बून 0

globule characteristics limited the free fat exposure to the camel milk powder surface.

3.1.2 Size distribution and densities of powder particles. The loose bulk density and the tapped bulk density of the produced camel and bovine milk powders are presented in Table 2 . The highest loose bulk density and the tapped bulk density were recorded for camel milk powders as compared to those of bovine milk powders $(P<0.05$, Table 2$)$. Similar observations were previously reported by Habtegebriel et al. (2018) and Zouari, Mtibaa, et al. (2020). These authors reported that camel milk powders presented higher bulk densities than those observed for bovine milk powders. Interestingly, for both milk powders, the loose and tapped bulk densities decreased, while powder fat and free fat contents increased $(P<0.05$, Table 2). Kim, Chen, and Pearce (2005a) indicated that the free fat amount impacted the flowability and the loose bulk density of milk powder. Indeed, this author reported that the removal of surface free fat induced an increase in the flowability and the bulk density of the powders. This explained the highest bulk density of camel milk powder as compared to those of bovine ones, since camel milk powder showed the lowest surface free fat content.

In our study, the analysis of the powder particles size distribution highlighted that camel milk powders have significantly lower $d_{50}$ than that of bovine milk powders $(P<0.05$, Table 2$)$. The width of the size distribution is usually evaluated by measuring the span value. For all produced camel and bovine milk powders, the span value ranged from $1.3 \pm 0.1$ to $2.1 \pm 0.1$ for bovine milk powders and from $1.4 \pm 0.1$ to $1.9 \pm 0.1$ for camel milk powders (Table 2). Analyses of the $d_{50}$ and the span indicated that the produced camel and bovine milk powders presented a narrow size distribution with low $d_{50}$. This indicated that these powders were composed of fine particles. Such kind of powders resulted in high bulk density (Barbosa-Canovas, Ortega-Rivas, Juliano, \& Hong, 2005).

Besides, results of this study indicated that by increasing the inlet drying temperature, the $d_{50}$ decreased while the span is increasing. This indicated that at high drying temperature, larger particles were produced. Our results are in agreement with Fang, Rogers, Selomulya, and Chen (2012) who reported that the inlet drying temperature affected the powder particle size. Indeed, these authors demonstrated that the particles were larger when dried at high temperatures due to rapid water removal and the high occurrences of particle shrinkage. This resulted in larger particle size (lower $d_{50}$ ) and wider size distribution (higher span).

3.1.3 Whey protein nitrogen index. The Whey protein nitrogen index (WPNI) of the produced camel and bovine milk powders is presented in Table 2 . This index is widely used in dairy industry to classify the produced powders (from very low heat treatment to high heat treatment) based on the heat sensitivity of some whey proteins (Schuck et al., 2012). In this study, the produced camel or bovine milk powders showed approximately the same WPNI (around 8.5 and $9.6 \mathrm{~g}$ of $\mathrm{N}_{2} / \mathrm{kg}$ ) regardless of the inlet drying temperature (Table 2). Indeed, it was reported that the outlet drying temperature is the most denaturizing temperature. During drying, the particles temperature quickly reaches the outlet drying temperature (Woo, \& Bhandar, 2013), which explained the similarities of the obtained WPNI.

However, we noticed that whole-fat and skimmed camel milk powder were less denaturized than those of bovine ones $(P<0.05$, Table 2). This could be related to the whey protein composition of both camel and bovine milks and their heat sensitivity. In fact, Farah (1986) analyzed the heat denaturation of camel whey proteins by 
Table 2-Physicochemical characteristics of bovine and camel milk powders.

\begin{tabular}{|c|c|c|c|c|c|c|c|c|}
\hline \multirow{3}{*}{$\begin{array}{l}\begin{array}{l}\text { Inlet } \backslash \text { outlet } \\
\text { temperatures }\end{array} \\
\text { Milk powder }\end{array}$} & \multicolumn{6}{|c|}{ Skimmed milk powders } & \multirow{2}{*}{\multicolumn{2}{|c|}{$\frac{\text { Whole-fat milk powder }}{200 \backslash 80^{\circ} \mathrm{C}}$}} \\
\hline & \multicolumn{2}{|c|}{$160 \backslash 80^{\circ} \mathrm{C}$} & \multicolumn{2}{|c|}{$180 \backslash 80^{\circ} \mathrm{C}$} & \multicolumn{2}{|c|}{$200 \backslash 80^{\circ} \mathrm{C}$} & & \\
\hline & Bovine & Camel & Bovine & Camel & Bovine & Camel & Bovine & Camel \\
\hline Free fats ${ }^{\#}$ & $23.0 \pm 0.1^{\mathrm{a}}$ & $10.0 \pm 0.1^{\mathrm{b}}$ & $20.0 \pm 0.1^{c}$ & $10.0 \pm 0.1^{\mathrm{b}}$ & $20.0 \pm 0.1^{\mathrm{c}}$ & $15.0 \pm 0.1^{\mathrm{d}}$ & $42.8 \pm 1.0^{\mathrm{e}}$ & $25.4 \pm 2.1^{\mathrm{a}}$ \\
\hline WPNI ( $g$ of $\mathrm{N}_{2} / \mathrm{kg}$ ) & $8.59 \pm 0.1^{\mathrm{a}}$ & $9.74 \pm 0.1^{\mathrm{b}}$ & $8.58 \pm 0.1^{\mathrm{a}}$ & $9.65 \pm 0.1^{\mathrm{b}}$ & $8.51 \pm 0.1^{\mathrm{a}}$ & $9.65 \pm 0.1^{\mathrm{b}}$ & $8.63 \pm 0.1^{\mathrm{a}}$ & $9.63 \pm 0.1^{\mathrm{b}}$ \\
\hline $\begin{array}{l}\text { Size distribution } \\
d_{50}(u \mathrm{~m})\end{array}$ & \multicolumn{3}{|c|}{ Size distribution } & & & & & \\
\hline Span & $0.1^{\mathrm{a}}$ & $1.4=$ & $1.4 \pm 0.1^{\mathrm{a}, \mathrm{b}}$ & $1.6=$ & $.7 \pm 0.1^{\mathrm{b}}$ & $\begin{array}{l}8.8 \pm 0.2 \\
1.9 \pm 0.1^{\mathrm{b}, \mathrm{c}}\end{array}$ & $\begin{array}{l}12.5 \pm 0.1^{\mathrm{c}} \\
2.1 \pm 0.1^{\mathrm{c}}\end{array}$ & $\begin{array}{l}10.5 \pm 0.2^{\mathrm{b}} \mathrm{c} \\
1.8 \pm 0.1^{\mathrm{b}, \mathrm{c}}\end{array}$ \\
\hline \multicolumn{9}{|l|}{ Densities $(\mathrm{kg} / \mathrm{m})$} \\
\hline Loose bulk density & $245 \pm 2.9^{\mathrm{a}}$ & $301 \pm 4.2^{\mathrm{b}}$ & $231 \pm 2.9^{c}$ & $299 \pm 2.4^{b}$ & $257 \pm 5.8^{\mathrm{d}}$ & $289 \pm 2.6^{\mathrm{e}}$ & $202 \pm 1.1^{\mathrm{f}}$ & $231 \pm 2.5^{c}$ \\
\hline Tapped bulk density & $458 \pm 5.5^{\mathrm{a}, \mathrm{d}}$ & $558 \pm 6.1^{\mathrm{b}}$ & $455 \pm 1.6^{\mathrm{a}}$ & $558 \pm 1.9^{\mathrm{b}}$ & $468 \pm 6.9^{\mathrm{d}}$ & $518 \pm 5.7^{\mathrm{e}}$ & $378 \pm 3.5^{f}$ & $419 \pm 4.2^{\mathrm{g}}$ \\
\hline \multicolumn{9}{|l|}{ Rehydration ability } \\
\hline Insolubility Index (mL) & $0.5 \pm 0.1^{\mathrm{a}}$ & $1.0 \pm 0.1^{\mathrm{b}}$ & $0.1 \pm 0.01^{\mathrm{c}}$ & $0.1 \pm 0.01^{c}$ & $0.1 \pm 0.01^{\mathrm{c}}$ & $0.1 \pm 0.01^{\mathrm{c}}$ & $0.5 \pm 0.1^{\mathrm{a}}$ & $0.3 \pm 0.1^{\mathrm{a}}$ \\
\hline Wettability (n & $55 \pm 3.0^{\mathrm{a}}$ & $52 \pm 2.0^{\mathrm{a}}$ & $44 \pm 1.0^{\mathrm{b}}$ & $46 \pm 3.0^{\mathrm{b}}$ & $27.0 \pm 3.0^{c}$ & $28.0 \pm 2.0^{c}$ & $65.0 \pm 2.0^{\mathrm{d}}$ & $68.0 \pm 2.0^{\mathrm{d}}$ \\
\hline Dispersibility (\%) & $74.3 \pm 0.1^{\mathrm{a}}$ & $74.4 \pm 0.4^{\mathrm{a}}$ & $81.5 \pm 0.8^{\mathrm{b}}$ & $91.0 \pm 0.1^{c}$ & $91.0 \pm 0.1^{\mathrm{c}}$ & $90.0 \pm 0.2^{\mathrm{d}}$ & $41.9 \pm 1.3^{\mathrm{e}}$ & $45.5 \pm 0.9^{\mathrm{f}}$ \\
\hline
\end{tabular}

\#: g/100 g of total powder fat.

WPNI, whey protein nitrogen index.

Same letter in the same row represents the statistical data significance $(P>0.05)$.

means of WPNI and concluded that camel milk whey proteins had a significantly lower heat sensitivity than those of bovine milk. This explained the highest WPNI of camel milk powders.

3.1.4 Rehydration properties. The rehydration characteristics of the produced powders are presented in Table 2. The rehydration properties reflect the reconstitution ability of the milk powder in water. Our findings showed that the insolubility indexes of skimmed or whole-fat milk powders ranged from 1 to $0.1 \mathrm{~mL}$, which corresponds to a solubility of $99 \%$ to $99.9 \%$. This result was in agreement with the literature data since it was reported that the solubility of spray-dried skimmed bovine milk powder is usually higher than 99\% (Pugliese et al., 2017). The highest insolubility index (IS $=1 \mathrm{~mL}$, i.e., a solubility of $99 \%$ ) was recorded for camel milk powder produced using low air inlet drying temperatures $\left(160 \backslash 80^{\circ} \mathrm{C}\right)$.

In addition, skimmed or whole-fat camel and bovine milk powders showed a wettability time higher or close to $30 \mathrm{~min}$ for all produced powders. Several studies showed that the wettability is dependent on the surface characteristics and the size distribution of milk powder particles (Gaiani, Banon, Scher, Schuck, \& Hardy, 2005; Kim, Chen, \& Pearce, 2002). In the current study, all measured $d_{50}$ of all produced camel and bovine milk powders were lower or closer to $12 \mu \mathrm{m}$. Such powder granulometry limited the water penetration inside the milk powder leading to a low powder wettability (Gaiani et al., 2005). Moreover, both milk powders dispersibility values have increased with the intensification of the drying temperature and the decrease of the particles $d_{50}$. The highest DI $(\mathrm{DI}=90 \%)$ was recorded for both milk powders at the drying temperature of $200 \backslash 80^{\circ} \mathrm{C}$. Langrish, Marquez, and Kota (2006) have reported that at low inlet air drying temperatures, the produced particles showed a collapsed structure with a high bulk density. This could limit the water penetration to the powder particles, which may lead to a low wettability and dispersibility. Furthermore, it was shown that some technological assessments, such as instantization and agglomeration, are able to enhance the wettability and dispersibility of milk powders. In fact, these techniques reduce the particles bulk density through increasing their size distribution making them porous (Cruz et al., 2005). This facilitates the water penetration to the particles and improves the wettability and dispersibility of milk powders. It is important to note that the dispersibility of whole-fat camel and bovine milk powders decreased drastically as compared to the skimmed ones (Table 2).
This could be linked to the exposed fat at the powder particle surface, which could limit the powder dispersibility in water (Zouari, Schuck et al., 2020).

For the rest of the study, the drying temperatures of $200 \backslash 80^{\circ} \mathrm{C}$ were adopted since the resulting powders showed the best rehydration properties (Table 2).

\subsection{Melting behavior of camel and bovine milk fats within the powder and in anhydrous state}

The melting properties of fats mainly depend on their fatty acid and triacylglycerol composition, on the dispersion of the fat (in emulsion droplets or in an anhydrous state) and on the applied thermal kinetics. Figure 1 shows the differential scanning calorimetry (DSC) thermograms recorded on heating of wholefat camel and bovine milk powders and the respective anhydrous fats obtained after extraction. The DSC thermograms recorded for whole fat camel milk powders exhibited three main endotherms corresponding to the successive melting of groups of triacylglycerols dispersed within the lipid droplets, with a final melting point of $46.3 \pm 0.2{ }^{\circ} \mathrm{C}$ (Figure 1Aa). On heating, the anhydrous camel milk fat exhibited four successive endotherms, with a final melting point of $45.1 \pm 0.2{ }^{\circ} \mathrm{C}$ (Figure 1Ba). The differences in the final melting points could be attributed to the formation of different crystals. The DSC melting thermograms recorded for camel milk fat are in agreement with previous studies (Lopez, Karray, Lesieur, \& Ollivon, 2005). The DSC thermograms recorded for whole fat bovine milk powders and anhydrous bovine milk fat exhibited four main endotherms, with final melting points of $39.8 \pm 0.5^{\circ} \mathrm{C}$ and $38.8 \pm 0.5^{\circ} \mathrm{C}$ (Figure $1 \mathrm{Ab}$ and $\mathrm{Bb}$ ). Our study perfectly agrees with the data reported by Kim, Chen, and Pearce (2005b) and Vignolles et al. (2009). These authors found that the melting temperature significantly decreased from $40.2^{\circ} \mathrm{C}$ (for whole-fat bovine milk powder) to $39.8^{\circ} \mathrm{C}$ (for anhydrous bovine milk fat) showing four distinct endothermic peaks.

The different melting properties observed between camel milk fat and bovine milk fat, either dispersed within the powder particles or in anhydrous state, are mainly governed by the differences in the fatty acid composition (Karray et al., 2005). From a technological point of view, the DSC determinations highlighted the fact that the milk fats will be at least partially in a solid state below their final melting temperatures. 

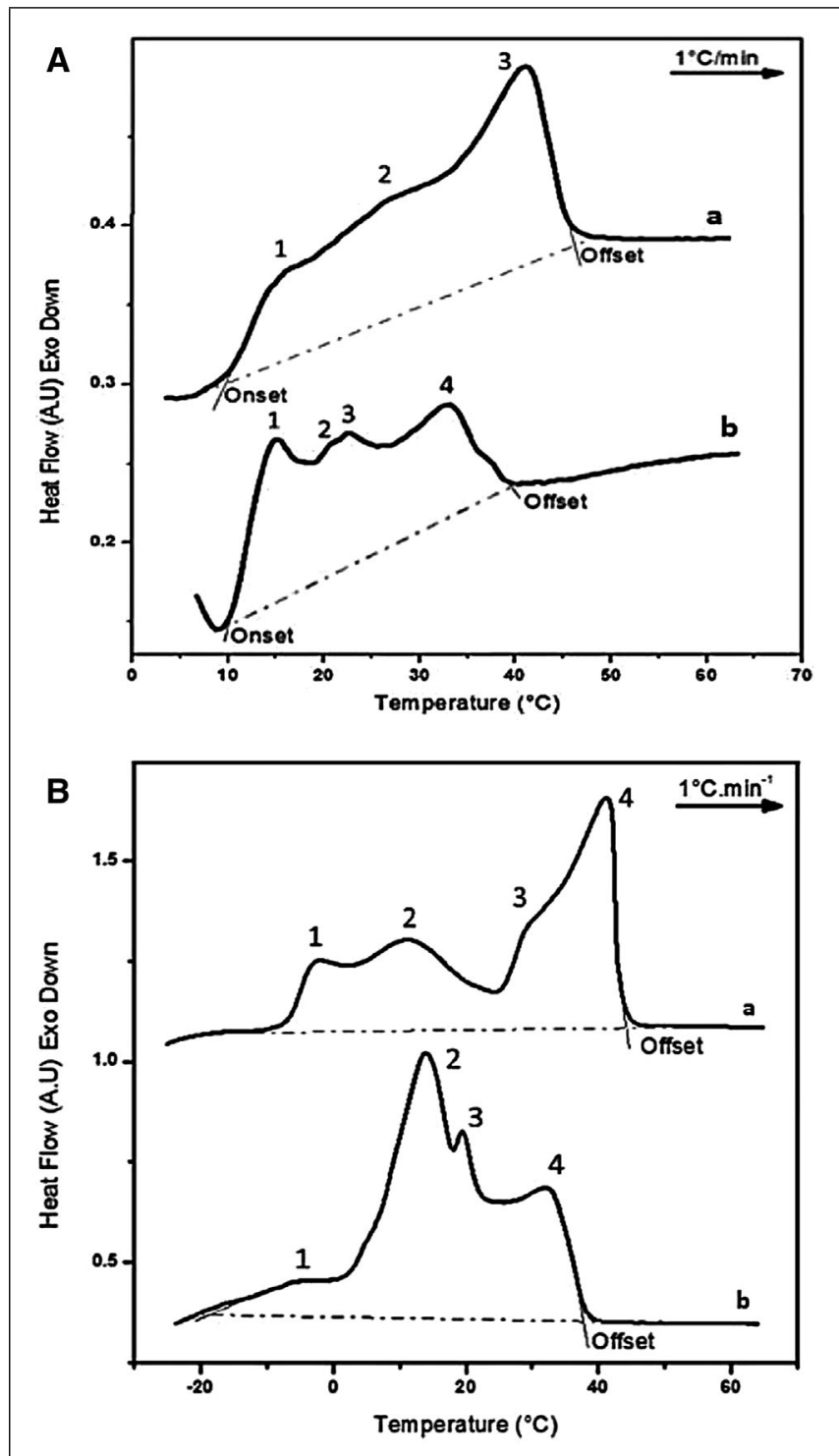

Figure 1-Differential scanning calorimetry thermograms recorded on heating of (A) whole-fat milk powders (a: camel; b: bovine) and (B) anhydrous fat extracted from the powders (a: camel; b: bovine).

\subsection{Protein analysis}

Figure 2 shows the SDS-PAGE patterns of skim (A, C) and reconstituted $(\mathrm{B}, \mathrm{D})$ camel and bovine milks, respectively. Under the denaturizing conditions, the SDS-PAGE gives an approximation of the denaturation extent of the spray drying on camel and bovine milk proteins. The first detected bands had a molecular weight ranging from 60 to $100 \mathrm{kDa}$ (Figure 2). These bands were attributed to some whey proteins, of which the latest band corresponded to the serum albumin (Figure 2, bands 5, 16, 28, and 38). The estimated molecular weight $(\mathrm{MW})$ of this protein was equal to $66 \mathrm{kDa}$ for both camel and bovine milks. In addition, some other whey proteins were detected in skimmed and reconstituted camel milks corresponding to the PGRP (Figure 2, bands 10 and 22, MW $=18 \mathrm{kDa}$ ) and $\alpha-\mathrm{La}$ (Figure 2, bands 11 and 23, MW $=14 \mathrm{kDa}$ ), respectively. In addition, the $\beta$ - $\mathrm{Lg}$ (Figure 2C, bands 32 and 42, $\mathrm{MW}=15 \mathrm{kDa}$ ) and the $\alpha$-La (Figure 2, bands 33 and 43, MW = $11 \mathrm{kDa}$ ) were identified in bovine milk. Our results highlighted the absence of $\beta$-Lg in both skimmed and reconstituted camel milk as already reported by several previous studies (El-Hatmi, Girardet, Gaillard, Yahyaoui, \& Attia, 2007; Felfoul et al., 2017; Lajnaf et al., 2018). It was reported that the $\beta$-Lg was the most heat-sensitive protein in bovine milk (Corredig \& Dalgleish, 1999). Its absence from camel milk further endorsed the highest measured WPNI for camel milk powders.

The camel milk caseins fraction showed comparable proteins composition with that of bovine milk. In fact, some identified bands were attributed to $\alpha$-casein (Figure 2, bands 7, 18, 19, 30, and 40), $\beta$-casein (Figure 2, bands 6, 17, 29, and 39), and $\kappa$-casein (Figure 2, bands 8,20,31, and 41). For skimmed and reconstituted camel milks, the estimated molecular weights were equal to 35,27 , and $18 \mathrm{kDa}$ for $\beta$-casein, $\alpha$-casein, and $\kappa$-casein, respectively. The $\alpha_{\mathrm{s} 1}$-casein (Figure 2, band 18) and $\alpha_{\mathrm{s} 2}$-casein (Figure 2, band 19) were only detected in reconstituted camel milk with molecular weights of 25 and $27 \mathrm{kDa}$, respectively. Our results are in perfect agreement with several studies (Ereifej, Alu'datt, Alkhalidy, Alli, \& Rababah, 2011; Felfoul et al., 2017; Omar et al., 2016).

According to the present SDS-PAGE analysis, there was no disappearance or appearance of new bands between both skimmed and reconstituted bovine and camel milks. This confirmed the high solubility indexes of camel and bovine milk powders (>99.9\%). Indeed, it was reported that the alteration of powder solubility is mainly a consequence of milk protein denaturation and/or aggregation through hydrophobic linkages (Thomas, Scher, DesorbyBanon, \& Desorby, 2004). At this stage of the study, the SDS-PAGE together with the WPNI analysis indicated that the amount of insoluble material was relatively low to alter the solubility of camel and bovine milk powders.

\subsection{Foaming properties}

Figure 3 illustrates the foaming properties of skimmed (before drying) and reconstituted (after drying) camel and bovine milks. In this study, significant higher foaming properties were recorded for the reconstituted milks as compared to those of skimmed ones $(P<0.05$, Figure 3$)$. Our findings indicated that reconstituted camel milk powder presented the highest foaming properties with $78.33 \pm 2.63 \%$ and $480 \pm 60 \mathrm{~s}$ for foam capacity (FC) and stability (FS), respectively. The skimmed camel milk (before drying) presented a FC and a FS of $68.33 \pm 2.88 \%$ and $253 \pm 50$ s, respectively.

Furthermore, results of the current study indicated that the reconstituted bovine milk exhibited a FC and a FS of $72.33 \pm 3.05 \%$ and $330 \pm 36 \mathrm{~s}$, respectively. These values were significantly higher than that observed for skimmed bovine milk $(57.0 \pm 2.63 \%$ and $210 \pm 30 \mathrm{~s}$ for FC and FS, respectively). It is worth noticed that, either as skimmed or reconstituted, camel milk displayed higher FC and stability.

Similar findings were reported by Augustin and Clarke (2008). These authors found that spray drying at $170^{\circ} \mathrm{C}$ improved the $\mathrm{FC}$ of the bovine milk proteins. We admitted that the improvement of foam properties is highly depended on the physicochemical state of milk proteins. In fact, it was reported that during heat treatment, a partial deployment of whey proteins occurred (Corredig \& Dalgleish, 1999). We hypothesize that, even if the time contact between the milk proteins and the warm-air was relatively short, a little whey proteins' denaturation could occur as a result of overdrying (low water content of the produced powders, Table 1). Such denaturation, as shown by SDS-PAGE and WPNI, enhanced the whey protein flexibility and participated in the improvement of the FC and stability (Osorio et al., 2014; Schmidt \& McNeill, 1993). 


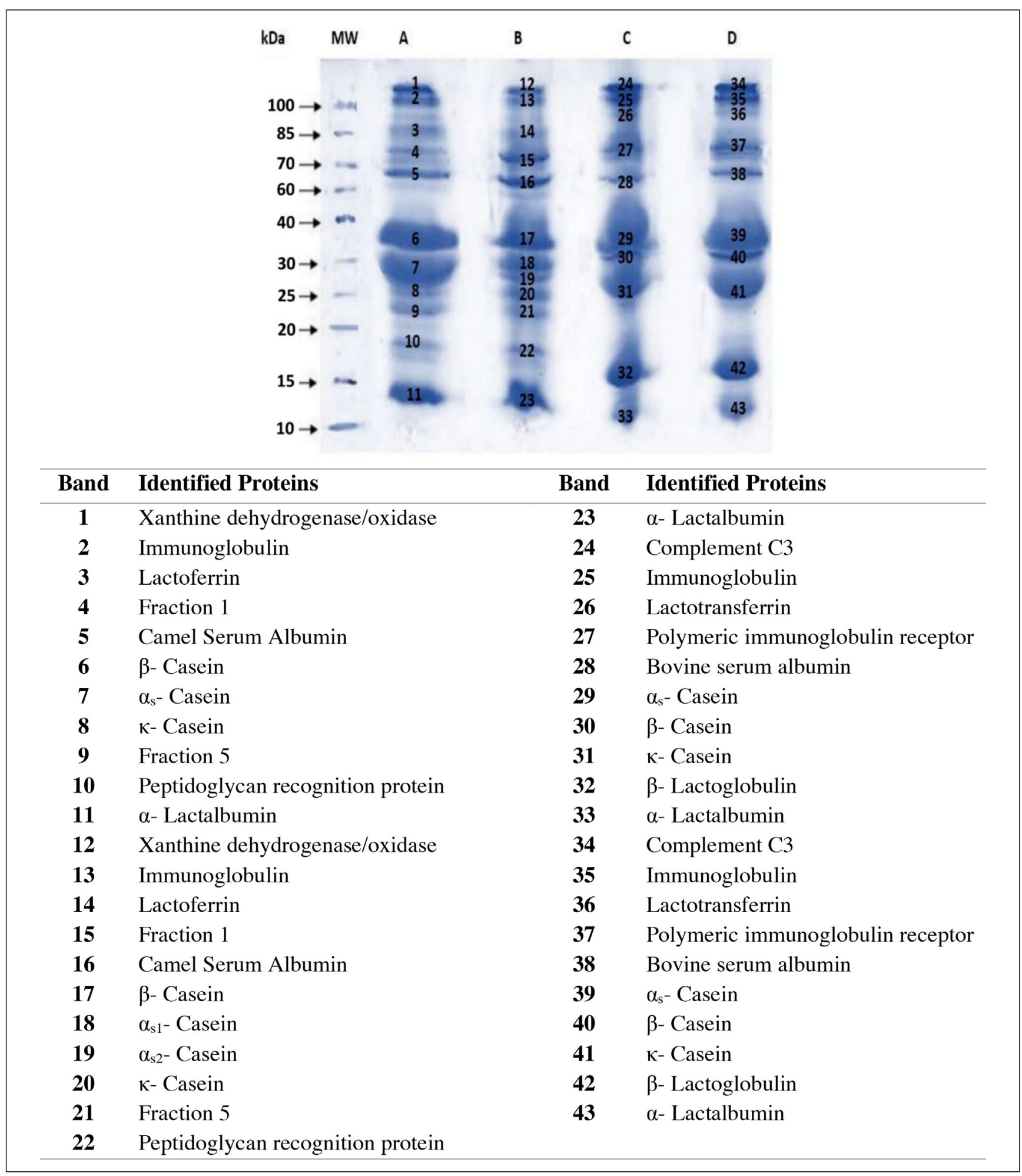

Figure 2-SDS-PAGE patterns of skimmed and reconstituted camel (A and B, respectively) and bovine (C and D, respectively) milks. Molecular Weight (MW): protein markers (10 to $100 \mathrm{kDa}$ ). Note: The proteins were identified based on the estimated molecular weights, the Uniprot Database (http://www.uniprot. org/), and the following studies: Ereifej et al. (2011); Felfoul et al. (2017); Omar et al. (2016).

\section{CONCLUSION}

In this work, three skimmed and one whole-fat camel milk powders were produced under various spray-drying parameters. The physical, biochemical, and rehydration characteristics, as well as the fat melting properties of these powders, were investigated and compared to those of bovine milk powders. Results of this study indicated that the composition of camel and bovine milks and powders was similar regarding the fat, protein, and lactose 


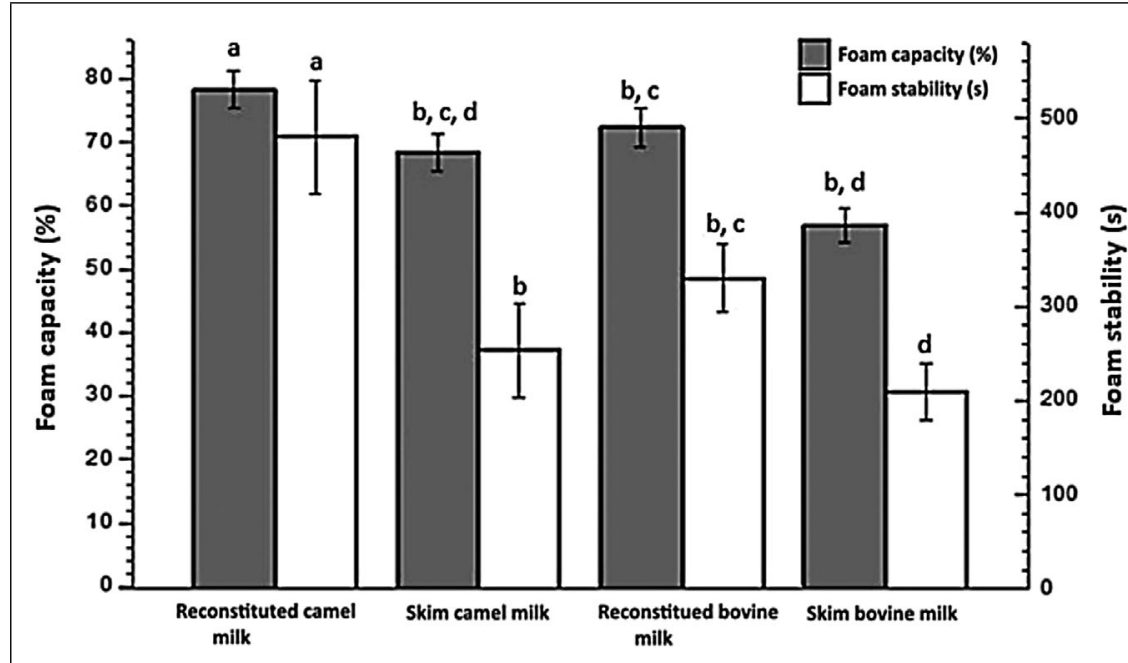

Figure 3-Foaming capacity and stability of skimmed (before drying) and reconstituted (before drying) camel and bovine milks. Same letter for each characteristic indicated the statistical data significance $(P>0.05)$. contents. However, the findings indicated that higher whey proteins and ash contents were observed in camel milk powders as compared to the bovine ones. In addition, the investigated camel and bovine milk powders presented a low $d_{50}(\leq 12 \mu \mathrm{m})$ and a span ranging from 1.3 to 2.1 . This indicated that these powders were composed of fine particles. Such kind of particles highly impacted the wettability and dispersibility of camel and bovine powders with no influence on their solubility (>99\%). Furthermore, it is worth noticed the highest bulk density of camel milk powder as compared to those of bovine ones. Besides, analysis of the WPNI indicated that regardless of the fat content, camel milk powders (WPNI $\approx 9.6 \mathrm{~g}$ of $\mathrm{N}_{2} / \mathrm{kg}$ ) were less denaturized than those of bovine ones (WPNI $\approx 8.5 \mathrm{~g}$ of $\mathrm{N}_{2} / \mathrm{kg}$ ). This was linked to the absence of $\beta-\mathrm{Lg}$ from camel milk as indicated by the SDS-PAGE. The latter analysis together with the WPNI showed that camel and bovine milk proteins were relatively stable during spray drying (low denaturation extent). This trend was related to the low outlet drying temperature of $80^{\circ} \mathrm{C}$. This low denaturation extent improved the FC and stability of camel and bovine milk powders. The present work gives some insightful information about camel milk powder processing, which could help researchers and industrials to conduct further investigations.

\section{ACKNOWLEDGMENT}

We would like to thank Mrs. Sawssen Derbel-Krichen for editing and improving the form of the manuscript.

\section{CONFLICTS OF INTEREST}

The authors declare no conflicts of interest.

\section{AUTHOR CONTRIBUTIONS}

Ahmed Zouari was involved with the conceptualization, methodology, software, visualization, investigation, writingoriginal draft preparation, reviewing, and editing of the article.

Roua Lajnaf, Christelle Lopez, and Pierre Schuck contributed to the conceptualization, visualization, and investigation.

Hamadi Attia was responsible for supervision.

Mohamed Ali Ayadi helped with the conceptualization, supervision, reviewing, and editing.

\section{REFERENCES}

Augustin, M. A., \& Clarke, P. T. (2008). Skim milk powders with enhanced foaming and steamfrothing properties. Dairy Science and Technology, 88, 149-161.
Barbosa-Canovas, G., Ortega-Rivas, E., Juliano, P., \& Hong, Y. (2005). Food powders. Physical prop erties, processing, and functionality. New York: Kluwer Academic/Plenum Publishers.

Corredig, M., \& Dalgleish, D. G. (1999). The mechanisms of the heat-induced interaction of whey proteins with casein micelles in milk. International Dairy Journal, 9, 233-236.

Cruz, M. A. A., Passos, M. L., \& Ferreira, W. R. (2005). Final drying of whole milk powder in vibrated-fluidized beds. Drying Technology, 23, 2021-2037.

El-Hatmi, H., Girardet, J. M., Gaillard, J. L., Yahyaoui, M. H., \& Attia, H. (2007). Characterisation of whey proteins of camel (Camelus dromedarius) milk and colostrum. Small Ruminant Research, $70,267-271$

Ereifej, K. I., Alu'datt, M. H., Alkhalidy, H. A., Alli, I., \& Rababah, T. (2011). Comparison and characterisation of fat and protein composition for camel milk from eight Jordanian locations. Food Chemistry, 127, 282-289.

Farah, Z. (1986). Effect of heat treatment on whey proteins of camel milk. Milchwissenschaft, 41, $763-765$.

Fang, Y., Rogers, S., Selomulya, C., \& Chen, X. D. (2012). Functionality of milk protein concentrate: Effect of spray drying temperature. Biochemical Engineering Journal, 62, 101-105.

Felfoul, I., Beaucher, E., Cauty, C., Attia, H., Gaucheron, F., \& Ayadi, M. A. (2016). Deposit generation during camel and cow milk heating: Microstructure and chemical composition. Food and Bioprocess Technology, 9, 1268-1275

Felfoul, I., Jardin, J., Gaucheron, F., Attia, H., \& Ayadi, M. A. (2017). Proteomic profiling of camel and cow milk proteins under heat treatment. Food Chemistry, 216, 161-169.

Gaiani, C., Banon, S., Scher, J., Schuck, P., \& Hardy, J. (2005). Use of a turbidity sensor to characterize micellar casein powder rehydration: Influence of some technological effects. Journal of Dairy Science, 88, 2700-2706.

Habtegebriel, H., Edward,D., Wawire, M., Sila, D., \& Seifu, E. (2018). Effect of operating parameters on the surface and physico-chemical properties of spray-dried camel milk powders. Food and Bioproducts Processing, 112, 137-149.

Haque, E., Bhandari, B. R., Gidley, M. J., Deeth, H. C., \& Whittaker, A. K. (2015). Change in molecular structure and dynamics of protein in milk protein concentrate powder upon ageing by solid-state carbon NMR. Food Hydrocolloids, 44, 66-70.

Ho, T. M., Chan, S., Yago, A. J. E., Shravya, R., Bhandari, B. R., \& Bansal, N. (2019). Changes in physicochemical properties of spray-dried camel milk powder over accelerated storage. Food Chemistry, 295, 224-233.

Jouppila, K., Kansikas, J., \& Roos, Y. H. (1997). Glass transition, water plasticization, and lactose crystallization in skim milk powder. Journal of Dairy Science, 80, 3152-3160.

Kappeler, S. R., Heuberger, C., Farah, Z., \& Puhan, Z. (2004). Expression of the peptidoglycan recognition protein, PGRP, in the lactating mammary gland. Journal of Dairy Science, 87, 26602668

Karray, N., Lopez, C., Ollivon, M., \& Attia, H. (2005). La matière grasse du lait de dromadaire: Composition, microstructure et polymorphisme. Une revue. Oléagineux, Corps gras, Lipides, 12, 439-446.

Kim, E. H.-J., Chen, X. D., \& Pearce, D. (2002). Surface characterization of four industrial spraydried dairy powders in relation to chemical composition, structure and wetting property. Colloids and Surfaces B: Biointerfaces, 26, 197-212.

Kim, E. H.-J., Chen, X. D., \& Pearce, D. (2005a). Effect of surface composition on the flowability of industrial spray-dried dairy powders. Colloids and Surfaces B: Biointerfaces, 46, 182-187.

Kim, E. H.-J., Chen, X. D., \& Pearce, D. (2005b). Melting characteristics of fat present on the surface of industrial spray-dried dairy powders. Colloids and Surfaces B: Biointerfaces, $42,1-8$.

Kleyn, D. H., Lynch, J. M., Barbano, D. M., Bloom, M. J., \& Mitchell, M. W. (2001). Determination of fat in raw and processed milks by the Gerber method: Collaborative study. Journal of $A O A C$ International, 84, 1499-1508.

Konuspayeva, G., Faye, B., \& Loiseau, G. (2009). The composition of camel milk : A meta-analysis of the literature data. Journal of Food Composition and Analysis, 22, 95-101.

Laemmli, U. K. (1970). Cleavage of structural proteins during the assembly of the head of bacteriophage T4. Nature, 227, 680-685.

Lajnaf, R., Picart-Palmade, L., Cases, E., Attia, H., Marchesseau, S., \& Ayadi, M. A. (2018). The foaming properties of camel and bovine whey: The impact of $\mathrm{pH}$ and heat treatment. Food Chemistry, 240, 295-303.

Langrish, T. A. G., Marquez, N., \& Kota, K. (2006). An investigation and quantitative assessment of particle shape in milk powders from a laboratory-scale spray dryer. Drying Technology, 24, 1619-1630. 
Lopez, C., Karray, N., Lesieur, P., \& Ollivon, M. (2005). Crystallisation and melting properties of dromedary milk fat globules studied by X-ray diffraction and differential scanning calorimetry. Comparison with anhydrous dromedary milk fat. European Journal of Lipid Science and Technology, 107, 673-683.

Omar, A., Harbourne, N., \& Oruna-Concha, M. J. (2016). Quantification of major camel milk proteins by capillary electrophoresis. International Dairy Journal, 58, 31-35.

Osorio, J., Monjes, J., Pinto, M., Ramírez, C., Simpson, R., \& Vega, O. (2014). Effects of spray drying conditions and the addition of surfactants on the foaming properties of a whey protein concentrate. LWT - Food Science and Technology, 58, 109-115.

Pugliese, A., Cabassi, G., Chiavaro, E., Paciulli, M., Carini, E., \& Mucchetti, G. (2017). Physical characterization of whole and skim dried milk powders. Journal of Food Science and Technology, 54, 3433-3442.

Schmidt, K., \& McNeill, V. (1993). Effect of heat treatments on the functional properties of caseinate and whey protein isolate solutions. Milchwissenschaft, 48, 3-6.

Schuck, P., Blanchard, E., Dolivet, A., Méjean, S., Onillon, E., \& Jeantet, R. (2005). Water activity and glass transition in dairy ingredients. Le Lait, 85, 295-304.

Schuck, P., Dolivet, A., \& Jeantet, R. (2012). Analytical methods for food and dairy powders. John Wiley \& Sons.

Sharma, A., Jana, A. H., \& Chavan, R. S. (2012). Functionality of milk powders and milk-based powders for end use applications-A review. Comprehensive Reviews in Food Science and Food Safety, 11, 518-528.

Thomas, M.E. C., Scher, J., Desorby-Banon, S., \& Desorby, S. (2004). Milk powders ageing: Effect on physical and functional properties. Critical Reviews in Food Science and Nutrition, 44, 297-322.
Vignolles, M. L., Lopez, C., Ehrhardt, J.-J., Lambert, J., Méjean, S., Jeantet, R., \& Schuck, P. (2009). Methods' combination to investigate the suprastructure, composition and properties of fat in fat-filled dairy powders. Journal of Food Engineering, 94, 154-162.

Woo, M. W., \& Bhandari, B. (2013). Spray drying for food powder production. In Handbook of Food Powders (pp. 29-56). Woodhead Publishing.

Zouari, A., Briard-Bion, V., Schuck, P., Gaucheron, F., Delaplace, G., Attia, H., \& Ali Ayadi, M. (2020). Changes in physical and biochemical properties of spray dried camel and bovine milk powders. $L W T, 128,109437$.

Zouari, A., Marchesseau, S., Chevalier-Lucia, D., Raffard, G., Ayadi, M. A., \& Picart-Palmade, L. (2018). Acid gelation of raw and reconstituted spray-dried dromedary milk: A dynamic approach of gel structuring. International Dairy Journal, 81, 95-103.

Zouari, A., Mtibaa, I., Triki, M., Jridi, M., Zidi, D., Attia, H., \& Ayadi, M. A. (2020). Effect of spraydrying parameters on the solubility and the bulk density of camel milk powder: A response surface methodology approach. International Journal of Dairy Technology, 73, 616-624.

Zouari, A., Perrone, I. T., Schuck, P., Gaucheron, F., Dolivet, A., Attia, H., \& Ayadi, M. A. (2019) Effect of outlet drying temperature and milk fat content on the physicochemical characteristic of spray-dried camel milk powder. Drying Technology, 37, 1615-1624.

Zouari, A., Schuck, P., Gaucheron, F., Triki, M., Delaplace, G., Gauzelin-Gaiani, C., ... Ayadi, M. A. (2020). Microstructure and chemical composition of camel and cow milk powders'surface. LWT, 117, 108693. 